This item was submitted to Loughborough's Research Repository by the author.

Items in Figshare are protected by copyright, with all rights reserved, unless otherwise indicated.

\title{
Geographies of education and the significance of children, youth and families
}

PLEASE CITE THE PUBLISHED VERSION

http://dx.doi.org/10.1177/0309132510362601

PUBLISHER

(c) Sage

VERSION

AM (Accepted Manuscript)

LICENCE

CC BY-NC-ND 4.0

REPOSITORY RECORD

Holloway, Sarah L., Phil Hubbard, Heike Jons, and Helena Pimlott-Wilson. 2019. "Geographies of Education and the Significance of Children, Youth and Families". figshare. https://hdl.handle.net/2134/13797. 
This item was submitted to Loughborough's Institutional Repository (https://dspace.lboro.ac.uk/) by the author and is made available under the following Creative Commons Licence conditions.

\section{creative
commons}

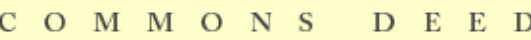

Attribution-NonCommercial-NoDerivs 2.5

You are free:

- to copy, distribute, display, and perform the work

Under the following conditions:

Attribution. You must attribute the work in the manner specified b the author or licensor.

Noncommercial. You may not use this work for commercial purposes.

No Derivative Works. You may not alter, transform, or build upon this work.

- For any reuse or distribution, you must make clear to others the license terms of this work.

- Any of these conditions can be waived if you get permission from the copyright holder.

Your fair use and other rights are in no way affected by the above.

This is a human-readable summary of the Leqal Code (the full license).

\section{Disclaimer 만}

For the full text of this licence, please go to: http://creativecommons.org/licenses/by-nc-nd/2.5/ 


\section{Geographies of education and the significance of children, youth and families}

To cite this paper: Holloway, S.L., Hubbard, P.J., Jöns, H. \& Pimlott-Wilson, H. (2010) 'Geographies of education and the importance of children, youth and families' Progress in Human Geography 34.5: 583-600

\section{Introduction}

In the first decade of the twenty-first century, geographers of diverse philosophical orientations, and with varied areal specialisms, have exhibited a growing interest in education (Butler and Hamnett, 2007; Collins and Coleman, 2008). The resulting literature has been incredibly wide-ranging, spanning studies of social reproduction (Aitken et al., 2006; Ansell, 2008), pre-school provision (Mahon, 2005; Smith et al., 2008), inequitable access to and attainment in compulsory education (Gibson and Asthana, 2000; Johnston et al., 2007), the (re)production of social difference within schools (Thomas 2005; Holt 2007), the design of individual schools (Kraftl 2006a; 2006b), global flows of students and academics (King and Ruiz-Gelices, 2003; Waters, 2005; Findlay et al., 2006; Jöns, 2009), the restructuring of tertiary education (Olds 2007; Hoyler and Jöns, 2008), and town-gown relations (Smith and Holt 2007; Hubbard, 2008). Whilst numerous conferences and conference sessions have sought to progress different aspects of these debates, this is not a field for which Anglophone geographers have sought recognition as a defined branch or specialism through their professional organisations ${ }^{1}$. Indeed, in a compelling paper in this journal, Hanson Thiem (2009) makes a case for an 'outward-looking' geography of education that deliberately avoids such sub-disciplinary confinement and instead situates education in the context of broader debates within the discipline.

In this paper we take Hanson Thiem's vision of a 'decentred' geography of education as our point of departure, providing a positive critique of this whilst outlining how an engagement with the literature on children, youth and families might further develop an understanding of educational spaces. Our discussion draws on a critical review of work in geography during the past decade, research that itself builds upon previous geographical initiatives, both in Anglophone geography (e.g., Hones and Ryba, 1972b; Marsden, 1977; Bondi and Matthews, 1988; Bradford et al., 1989; Gould, 1993) as well as in the German language tradition (Geipel, 1968, 1976; Meusburger, 1976, 1998)². 
Noting the breadth of existing research on geographies of education, we hence begin by discussing the benefits of Hanson Thiem's approach to educational restructuring in advanced capitalist political economies and her emphasis on questions of globalisation, neoliberalisation and knowledge economies. We then proceed to highlight the omissions in this vision, and argue that it is essential to complement her self-confessed 'limited yet indicative agenda' (2009: 167) with another that is more fully-informed by developments in social and cultural geography, and, in particular, geographical research on children, youth and families. The subsequent four sections of the paper then detail what geographies of education that pay due attention to children, youth and families might look like. To the extent that it is appropriate, these sections are designed to mirror those in Hanson Thiem's original paper, and thus relate to social geographies of education provision and consumption; formal and informal curricula and spaces of learning; knowledge spaces and student-centred geographies; and rethinking restructuring and social reproduction. In conclusion, we emphasise the implications of thinking about children, youth and families for future research on geographies of education.

\section{Reframing research: from political-economic to social-cultural geographies of education}

Hanson Thiem begins her discussion by returning to a paper by Bradford (1990) in which he discerned two strands of work on geographies of education, one essentially inward-looking, examining spatial variation in educational provision, and a more outward-looking one, using these spatial variations to comment on wider social, economic and political processes. One of the central tenets of Hanson Thiem's argument is that inward-looking studies, though useful in identifying inequality and studying educational reform, are limited in their conceptualisation of education spaces as essentially shaped by wider processes. Instead, she argues for the further development of outward-looking analyses which explore the constitutive properties of education spaces - 'how education “makes space”' (Hanson Thiem, 2009: 157) - or use education as a case study in order to explore wider cultural, social, political and economic processes.

We have considerable sympathy for the argument that such geographies would make a fuller and deeper contribution to our understanding of globalisation, neoliberalism and 
knowledge economies. One problem for us, however, is that this division of past research into inward- and outward-looking categories relies on the exclusion from analysis of a significant body of research on school design, the (re)production of social difference within school space, as well as the links between home and educational spaces, produced by researchers interested in children, youth and families. This is a partiality which Hanson Thiem (2009: 169) acknowledges, and our intention here is not to berate her for this omission. She is clear that her paper represents 'one effort to “think through” education’ (2009: 167), and we concur with her assessment that the diversity of literature on geographies of education presents a challenge for reviewers. Instead, our aim is to present an alternative effort to think through education, one that includes this diverse body of research on geographies of children, youth and families. A key difference is that our (equally partial) view will focus less on the political-economy approach and will instead, by including the work of children's and young people's geographers as well as those interested in caring and parenting, consider the insights from a body of literature that is more often informed by feminist and post-structuralist theories.

\section{Social geographies of educational provision and consumption}

Education plays a vital role in the reproduction of cultural and economic capital. Differential access to education, and geographical variations in educational attainment, have thus been important themes in what might be considered inward-looking literature on geographies of education. However, the restructuring of educational provision in neoliberal economies is the focus of many of the best studies of access to education, examining, for example, the impacts of specific policies to increase diversity in educational provision and the introduction of rules promoting 'parental choice' (Gibson and Asthana, 2000; Taylor and Gorard, 2001). Underlying such studies is recognition that educational attainment fundamentally shapes students' future life chances. In this context, these studies lay bare the inequalities in access to education in advanced capitalist political economies, where many students from low-income families and minority ethnicities get a poor deal from state education (Freytag, 2003a, 2003b; Burgess and Wilson, 2005; Johnston et al., 2007; Burgess et al., 2008).

The question for us, then, is not simply how to make these studies more outwardlooking, but also how to develop their analyses of education as a vital sphere of social 
reproduction and inequality. Many of these studies are statistical in nature, some benefiting from advances in geo-demographic technique (Harris et al., 2007; Webber and Butler, 2007), and this form of work produces clear, if contested, analyses of social variation in access and attainment (Gibson and Asthana, 2000). The authors themselves note, however, that the correlations their studies produce do not necessarily equate to causality (Johnston et al., 2007), and they need to be complemented by an equal weight of studies which used mixed or qualitative methods to untangle the processes which led to unequal provision and outcomes. Warrington’s (2005) analysis of the school 'choices' of working class parents/carers with high-achieving children is insightful in this respect. She uses interviews with these parents/carers to trace the ways in which a minority succeeds in getting its children into 'good' schools, while the majority found their marginality reinforced as the choice of a good school was not, in reality, open to them. A more balanced approach, in which the crucial insights from rigorous quantitative work are augmented by explanatory depth of such qualitative approaches, will be crucial to the ongoing development of geographies of educational access and attainment attuned to the influence of both race/ethnicity and class (for an example of a mixed methods study that examines the situation of Hispanic people in New Mexico, USA, see Freytag, 2003a).

The need to balance insights from quantitative and qualitative work in studies focusing on provision and consumption of education is but one part of our argument. Equally important is our insistence that a reading of studies from a broader diversity of socialcultural contexts suggests a different characterisation of, and ways forward for, geographies of education provision and consumption. Firstly, there is considerable scope to broaden the conception of social difference upon which the field is based, which has to date been dominated by analyses of class and race/ethnicity. Valins (2003), for example, demonstrates the importance of addressing questions about faith-based communities in an analysis of Jewish day schools which explores how community leaders, with greater or lesser approval from parents, set out to construct and defend particular versions of Jewishness. In this case, the aim of community leaders is to use state-funded faith schooling to reproduce particular visions of Jewish identity, a process supported by the British Government in their pursuit of academic standards, and one which reinforces the identity of a minority group at the same time that it recreates lines of exclusion. In pursuing this line of research, Valins not only adds faith to the platter of social differences we might want to consider in social geographies of education, but 
also highlights some of the moral ambivalences in the interpretation of these geographies, in particular the tensions between the need for openness to others in a multicultural society and the equally strong-felt desire to maintain religious identity (see also Hemming, 2009).

Secondly, in examining the consumption of education by a broader diversity of social groups, we need to focus on the voices of, and ideas about, a group of social actors who are curiously invisible in much of the research cited above - namely, children and young people. Neither the statistical analyses of different social classes of children entering secondary schools, for example, nor studies of their parents' strategies for obtaining a school place, have given much insight into children's experiences of, and contributions to, these processes. Reay (2007) provides an innovative exception to this trend and her work is exemplary of potential ways in which children's voices might be included. Her exploration of children's experiences of the transition from primary to secondary school in a low income area includes an examination of the ways children talk about not wanting to be allocated places at local 'demonised' secondary schools, and how they manage their interpretations of self and school when sent there. As important as including children's and young people's voices is the need to include an examination of the ways our ideas about 'normal' and 'differentiated' childhood shape educational provision and consumption. Exemplary here is the work of Vanderbeck (2005), who examines how normative understandings of childhood, most notably 'universal' discourses about children's rights and their right to education, are mobilised in the context of Traveller Education Services, as in diverse ways state actors seek to include these minority ethnicity children in a settled community service which some, though not all, Traveller children and their parents regard as antithetical to their own cultural traditions.

The incorporation of studies concerned with childhood, children and young people is important as they demonstrate how educational provision is shaped by socially/culturally specific understandings of what childhood should be like, and deepen our understanding of children's experiences of education and their competencies as social actors in this field. When read alongside feminist research on caring responsibilities they also have the effect of extending our understanding of education. This is because researchers interested in children, youth and families have studied education across a wide age spectrum, and because their linked interest in children and 
parents has led them to focus not only on what happens within school time, but crucially also what happens at the beginning and end of the school day.

To expand, there is, for example, a small but significant tradition of research within this literature which looks at pre-school provision and examines how parents' use of diverse forms of 'educare' both shapes and is shaped by ideas about the meaning of childhood and what good mothers/parents are supposed to provide (Holloway, 1998, 1999; McDowell et al., 2005). Equally, there is a literature on travel to and from childcare and school, including studies of parents' gendered responsibilities, initiatives such as walking buses and analyses of what the journey to and from school means to children (Kearns et al., 2003; Pooley et al., 2005; Ross, 2007; Schwanen, 2007), as well as a policy-informing literature on children's experiences of after-school clubs (Smith and Barker, 2000, 2001, 2004). Taken together, this literature provides a more spatially diverse take on education, both broadening the range of institutional contexts which might be considered worthy of attention (including pre-school nurseries and after school clubs), but also crucially pointing to some of the non-institutional spaces in which education might take place (including the family home and neighbourhood spaces).

Cross-cutting all of these arguments, we would stress the need for geographies of educational provision and consumption to become more spatially diverse in a second way, namely, to become more global in their scope. Innovative exceptions to the fixation on the Global North illustrate the importance of exploring the geography of access and attainment in other parts of the globe. Cao's (2008) study, for example, which examines gendered access to compulsory-level education in remote, ethnicallydiverse parts of Western China, illustrates the potential of quantitative studies based on secondary data in contexts outside Western political economies, as well as the benefits that might be accrued by integrating these with more intensive research methods. Punch (2002, 2004) by contrast, uses ethnographic methods to study the (very limited) impact of formal education on young people’s future livelihoods, and young people's transitions from school to work, and a position of 'negotiated interdependence' with their parents, in a rural area of the Majority world. Her research, which emerged out of the field of children, youth and families research, illustrates the potential of qualitative research on education in the South, and does exactly what geographies of educational provision and consumption have been critiqued for failing to do in advanced capitalist societies: namely, explores the consequences of individuals' educational attainment and the ways this structures social space, for example, through the labour market. Jeffrey et 
al.’s (2004, 2007) ethnographic studies on the relationship between education and unemployment in rural north India are equally valuable in this respect. By pointing to the ambiguous effect of formal education for Dalit and Muslim young men, who are increasingly unable to gain secure employment, these studies problematise development initiatives that promote formal education as a means for gaining social standing and economic prosperity. In this sense, extending the spatial lens when envisioning geographies of education not only enables comparison of experiences in the global North with those in the global South, it also allows researchers who focus on the global North to learn from innovative work being undertaken there (see Gould, 1993).

In sum, our agenda for geographies of educational provision and consumption would involve a revaluing of statistical work on access and attainment and its integration with qualitative approaches; underpinning this would be a wider interpretation of what counts as a significant social difference and an engagement with both children/young people and ideas about childhood/youth in diverse spatial settings.

\section{Formal and informal curricula and spaces of learning}

Interest in geographical imaginaries has highlighted the importance of the curriculum in shaping different scales of identity and citizenship, whether regional, national or transnational, and their links with state and broader economic formations. Indeed, there is excellent research which traces the making of these identities through school and university curricula (Marsden, 2001; King and Ruiz-Gelices, 2003; Gagen, 2004; Kong, 2005) and, conversely, the implications for the curriculum of these identities by looking at the ways in which the transnational mobility of academics affects the nature of the curriculum in both the source and destination countries (Foote et al., 2008; Theobald, 2008).

To this agenda, we also need to add a focus on other aspects of identity which are not necessarily self-evidently geographical, including class, dis/ability, faith, gender, race and sexuality. One route into this would be through a focus on the shaping of the curriculum. Sometimes there are public struggles over this, as Collins (2006) reveals when he traces the importance of the public/private distinction in debates about the appropriateness of using books in schools which portray particular sexual identities (see also Collins, 2007, on the spatiality inherent in debate about the place of religion in 
American public schools). Equally important is research which looks at the role of the feminisation and masculinisation of the teaching profession in curriculum development and identity formation (Bondi and Domosh, 1992; Blumen, 2002).

A complementary strategy is to examine how children's and young people’s identities are reproduced and reworked through the socio-spatial practices underpinning the delivery and consumption of the curriculum in schools. Research in this field has tended to view schools as precarious geographical accomplishments (Philo and Parr, 2000) embedded within wider sets of social relations. These accomplishments, which themselves contain multi-layered cultures reflecting not just official school policy but also informal teacher practices and diverse pupil cultures, are always in the making and thus potentially open to change (Holloway et al., 2000). An historical context is given to such arguments in de Leeuw's (2007) study of 'Indian' residential schools in British Columbia, Canada, between 1861 and 1984. Here she examines both the policies and staff practices in these schools - where First Nations' young people were educated away from their parents in order to break their cultural links and assimilate them into subordinate positions within dominant Canadian society - as well as the impacts these had on young people (and their resistance to them). In the contemporary context Hemming (2007) and Evans (2006) both focus on sport and exercise in schools. In doing so, Hemming reveals the importance of an analysis of children's agency and adult-child relations in understanding the meaning of the curriculum in the fluid institution of the school, while Evans is more concerned with how older girls perform gendered and heterosexed identities in and through the school - performances which are central in shaping many young women's disaffection with sport in the curriculum. By contrast Valentine et al. (2002) focus on the production of social in/exclusion through the delivery of the Information and Communications Technologies (ICT) curriculum in schools. Their analysis focuses on the intersections of government policy (which has led to the uneven distribution of equipment between schools), school practices (where different understandings of ICT shape the socio-spatial organisation of provision within individual schools) and peer cultures (which lead some children to engage with and others to avoid such provision). The outcome is that some children gain skills advantageous in the labour market while others have less access to these.

What each of these four studies start to highlight is the importance of the informal as well as the formal curriculum in schools. While the design and administration of the curriculum is important, so too are the informal lessons which students learn, enforce, 
reject and rewrite in schools and post-compulsory education. Here the focus is not on the content of lessons, but the nature of socio-spatial relations within different learning spaces as well as children's and young people's identities and experiences (see, for example, Hyams, 2000; Nairn, 2003; Thomson, 2005; Collins and Coleman, 2008; Pike, 2008). One strand of this research which usefully enriches our understanding of geographies of education has been informed by (critical) readings of Butler's (1993) performative understanding of gender, illustrating the influence of feminist and poststructural thinking in research on children and young people. Thomas (2005), for example, works through these ideas in her analysis of racial segregation in a southern US high school, concluding that the effects of girls' everyday social practices (who they sit with at lunchtime, how they address one another etc) 'are racialized social differences, identities and spaces’ (Thomas, 2005: 1246; see also Thomas, 2008 on the links between 'banal' multiculturalism in US public school and racial-ethnic identification among girls from minority ethnic groups). Holt (2007) differs somewhat in her reading of Butler, but similarly shows how children's sociability within schools reproduces (dis)ability as an identity positioning. By contrast Ansell (2002) is unusual in that while she too draws on Butler she does so in a rare example of research concerned with gender identity construction in schools in the global South (see also Ansell, 2001). Much of the emphasis in these studies, which construct schools as 'spaces distinct from, but embedded within, the contexts of everyday life' (Ansell, 2002: 180), is on the consequences of these performances of identity for young people in the here-and-now. However, Ansell also rolls these forward to explore the mismatch between gender identities based on discourses of 'equal rights' and particular reworking of African 'culture' in school discussions, and the very limited likelihood of material conditions outside school that will make these performances a possibility.

The focus on the spaces of the curriculum is taken forward in a very different way in innovative work by Kraftl (2006a, 2006b). Instead of focusing on children’s geographies as the above studies have done, he is concerned with the ways in which adults construct, both literally and metaphorically, the geographies of childhood. Through a focus on a Steiner school in Wales (a co-operatively built and run school which falls outside mainstream state-funded education), he explores how 'alternative' views of childhood informed the design, construction and use of the school building, emphasising the importance of apparently banal objects (plastering, paint, door handles, nature tables, wall charts) which 'are enrolled in, and constitutive of, more pervasive, 
more-or-less coherent notions of childhood' at the school (Kraftl, 2006b: 501). In so doing, he points to a wider agenda that warrants further attention, specifically how adult(ist) notions of childhood structure the socio-spatial organisation of schooling (see also Collins and Coleman, 2008, on schools’ outdoor spaces).

Geographical research on the curriculum is, as the different 'takes' on this topic illustrated above demonstrate, a diverse and developing field of study. Crucially we have shown that such research needs not only to focus on self-evidently geographical identities, but also include an analysis of diverse forms of social difference in the design, delivery and consumption of the formal curriculum as well as their (re)production through the informal curriculum that permeates the precarious geographical achievements that are schools and other educational spaces. These spaces too demand attention, not least for the ways in which the design and use of school spaces is shaped by adult interpretations of ideal childhood. Our wider reading of what geographies of education might have to say about the curriculum, and a more positive interpretation of what has so far been achieved, stems from the inclusion of geographical literature relating to children, youth and families. These studies broaden our attention from a concern with the ways education produces future citizen-workers to include an analysis of young people's understanding of diverse identity-shaping practices within schools. These two interests ought not to be mutually exclusive, and the benefit of including the literature on children, youth and families is that it allows us to emphasize the importance of education for young people's contemporary experiences as well as their adult lives.

\section{Knowledge spaces and student-centred geographies}

Educational spaces are key sites in the production of competitive knowledge economies. Such connections between education and competitiveness are perhaps most explicit in the higher education sector, with the much cited work of Richard Florida (2002) on creativity cementing the idea that cities possessing higher proportions of educated residents are also most creative and productive. This is partly an acknowledgement that universities, traditionally autonomous from the state and market (Harloe and Perry, 2004) are becoming increasingly entrepreneurial, forging new relations with business and government at a variety of scales (Marginson and Considine, 2000; Canaan and Shumar, 2008). This is explicitly connected, in many cases, with strategies of 
internationalisation designed to improve universities’ position in circuits of expertise (Olds, 2007; Hoyler and Jöns, 2008). As such, ‘world-class’ university status has become a widely-shared aspiration for higher education institutes, with the assumption being that increased connection with other 'world-class' universities can promote job creation, innovation and creativity within the university's locality, region and nationstate, as well as bringing direct dividends in terms of increased fee income and investment (Altbach, 2003; Sadlak and Liu, 2007).

The internationalisation of higher education raises important questions about transnational education markets, and encourages geographers to widen their horizons beyond the immediate role of higher education institutions in local economies to consider wider issues of mobility, flow and embedment (e.g. Lambooy, 1997; Harloe and Perry, 2004; Hall, 2008), including their impacts across national boundaries through practices such as honorary degree conferment (Heffernan and Jöns, 2007). Yet, while the economic impacts of universities, and their capacity for stimulating regional economic growth and innovation, have been widely noted (e.g, Rutten et al., 2003; Benneworth and Charles, 2005; Lawton Smith, 2006; Vorley and Lawton Smith, 2007), there has been only limited attention devoted to the social and cultural geographies of students themselves (Hubbard, 2008). As potential members of Florida’s (2002) muchvaunted 'creative class', students may be conceptualised as integral to the development of competitive and diversified 'knowledge economies' but their lifestyles and impacts on university towns during their studies have rarely been regarded as a legitimate focus of study by geographers. However, recent research has begun to note significant transformations in the relationship between universities and local communities, with groups of residents in the UK, USA and Australia in particular beginning to accuse rapidly-expanding universities of creating socially-unbalanced communities in which the interests of transient and mainly young students are prioritised over those of longerterm residents (Allinson, 2006; Hubbard, 2008; Smith 2008). Given students often outcompete such residents in the housing market, such processes must be considered as analogous to gentrification in the sense that they can polarise and displace low-income groups from spaces that become increasingly devoted to student ways of life (Lees et al., 2007).

Captured in the neologism of studentification, the influx of students into particular neighbourhoods has resulted in deteriorating relationships between town and gown, 
prompting measures from local city councils, Student Unions and universities keen to rebuild bridges between students and local communities (Smith, 2005). However, it is evident that the impacts of studentification differ markedly across different communities, and that these impacts may well be more pronounced in the context of the UK than elsewhere. Many factors are significant here, such as the type of university, the nature of the local housing stock and the amount of accommodation provided oncampus. Whether off-campus accommodation is in the form of rental houses or purpose-built developments may also be significant, with the latter becoming increasingly important as a source of student accommodation in many UK towns and cities (Smith, 2008) as well as in the USA and Australia (Fincher and Shaw, 2006).

The extent of the resulting demographic imbalance is of course highly variable, but in its most intense forms, there is consensus that studentification 'reduces the opportunities for positive and mutually beneficial interactions between groups and fuels the segregation of populations based on lifestyle and life-course cleavages, as well as differing levels of economic capital' (Smith, 2008: 2549). Initial research in the UK suggests that such segregation is most sharply expressed in smaller university towns rather than the cities that have the largest overall student populations (Hubbard, 2008). Yet the assumption that the size of the student population in proportion to that of the host community is the key factor shaping community responses to students needs to be tempered with consideration of the social and cultural dispositions of students and the extent to which these are at odds with those of local residents (with whom they may share little in terms of social, economic and cultural background). Exclusionary urges expressed towards students may hence reveal underlying resentments based on class and age differences, suggestive of the need for an inter-generational perspective on studentification and student lifestyles.

Despite the emergence of a more outward-looking literature on students living beyond the campus, it is evident that major lacunae remain concerning the understanding of student lifestyles and housing choices, with most UK commentators describing a fairly standardised housing route involving a supervised leaving of the parental home (i.e. hall living) followed by a 'sheltered' spell in the private-rented sector and, upon graduation, a transition to owner-occupation. Chatterton (1999: 122) for example, notes that most students are involved in a 'process [which] represents annual learning of student rites and a distancing from the student infrastructure as the student is acculturated into less 
“typical” student activities within the city'. Explicit here is the idea that those students who remain in the parental home throughout their studies suffer disadvantages of reduced choices in higher education and the loss of the independence associated with 'authentic' student life. Holdsworth (2006) hence argues that residential status operates as a 'labelling device’ among students, distinguishing local and away students, mediating students' relationship to university and constructing ideas of the 'typical student'. For Rugg et al. (2004: 128), the student residence 'pathway' thus constitutes an 'essential education in housing that enhances the housing and labour opportunities of graduates compared with other young people who have not studied away from the parental home'.

Vital here too is consideration of students' familial and household arrangements. Holdsworth's aforementioned work with students living in their parent's home is exemplary in this regard, highlighting some of the factors which might encourage people to go to their local university, as well as some of the experiences of exclusion which they face by being positioned 'outside' the student body which lives on campus and in halls of residence (see also Patiniotis and Holdsworth, 2005). Likewise, Hopkins' (2006) use of diagramming methods with those about to go to university usefully illustrates some of the hopes and fears young people have about their time at university, and problematises any clear distinctions between children/adults as they apply to higher education. Emerging work on 'post-students' similarly develops understanding of graduate retention and point to the ways in which educational identities infuse other times and spaces.

Yet for all this it is important to note that students are diverse in their dispositions and outlook, and that not all students conform to (British) media stereotypes of being consumer-oriented and alcohol-fuelled. It is here that inspiration might be taken from work on children and youth cultures, with better understanding of diverse student cultures being necessary to appreciate the different ways in which students inhabit, transform and move through the places where they live and study. Studies such as Roy's (2009) on the diverse experiences of Indian students studying in London highlight a variegated experience of higher education, revealing diverse activity spaces among migrant student groups. Her study suggests that students exhibit varying degrees of attachment to their university campus, and that while some develop social networks very tightly tied to their place of study, others are more expansive in their outlook, with 
the university providing merely one node in their network of social contacts. While some of the students consumed the urban 'playscapes' that Chatterton (1999) and others suggest are responding to student demands for alcohol-based entertainment, Roy shows through the photographic diaries kept by her respondents that other off-campus spaces of communal eating (especially kitchens in shared houses), study (libraries) and leisure (parks and sports grounds) can be just as significant as sites of student sociality.

Putting students first in studies of the neoliberalisation of higher education thus seems crucial given they are both the key consumers, and outputs, of what has become an increasingly internationalised education industry: migration of students between higher education establishments is, after all, a move between different student cities, each with its own distinctive 'cultural offer' and residential landscapes (Brooks and Waters, 2009). Without such student-centred analyses of the experiences of student cities, work on the political economy of educational restructuring risks presenting anaemic accounts in which the choices of students are over-determined and prefigured rather than being the outcome of complex social relations that occur in specific cultural contexts.

\section{Rethinking restructuring: childhood, feminism, and responsibilities for social reproduction}

Geographers have shown considerable interest in the neo-liberal restructuring of the capitalist welfare states which developed during the course of the twentieth century (Esping-Andersen, 1990). Much of the literature has focused on its retrenchment, although in the past decade considerably more attention has also been paid to the state's rescaling and rolling out as well as its roll-back, as authors have examined the shift from Keynesian to workfare-oriented welfare states (Peck and Theodore, 2001; Jessop, 2002; Cochrane and Etherington, 2007). Mahon's (2005) analysis of the rescaling of social reproduction in Canada and Sweden is exemplary of an approach which might be further developed in studies of educational restructuring. Her focus is non-parental childcare provision, a context where changing gender relations (most notably the increased numbers of women in paid work and thus unavailable to provide care free of charge in the home) mean that States, not withstanding pressures to make cuts elsewhere, are under pressure to take more responsibility for this aspect of social reproduction. Mahon traces the ways in which responses to these changing demands coalesced in Toronto/Canada and Stockholm/Sweden. She demonstrates that contrary 
to welfare regime theory these demands were not simply met in ways consistent with their (respectively liberal and social-democratic) national welfare models, but that a multi-scalar analysis can uncover the possibility (though not guaranteed success) of path-shifting responses, for example as neoliberal forces in Stockholm challenged the social-democratic orthodoxy of the Swedish State. In this instance then, her focus on particular examples of state restructuring tells us about the impacts of that for the sector itself, but also works to inform theories of state restructuring (see also Holloway and Pimlott-Wilson, 2009).

Such examinations of state restructuring of education, which engage with and seek to inform political economy approaches to the state and governance in advanced capitalist economies, are an important strand in geographies of education. Mahon's study is particularly insightful as it does this through a case study which broadens the range of institutional spaces included within geographies of education. As we have argued during the course of this paper, an increased diversity in the spaces which count in geographies of education is also achieved through a reading of the literature on children, youth and families. Smith et al. (2008), for example, focus on the education and training opportunities provided to lone parents in ethnically-diverse West London, as part of workfare policies designed to increase their readiness for and entry into paid employment. They highlight the ways in which an ethnically-diverse group of lone parents are being steered towards education and training that will equip them for lowpaid work in the childcare sector, employment that is necessary to service the needs of highly-paid dual earner couples in the West London economy. Rather than tackling inequality through the inclusion of lone parents in the labour market, the workfare approach of New Deal for Lone Parents risks reproducing class difference in new ways, as lone parents are encouraged to move off benefits and into low-paid work, looking after other people's, rather than their own, children. Such studies not only expand the range of institutional spaces that count in geographies of education but demand an examination of the consequences of state restructuring for differently gendered, racialised and classed subjects.

Engaging with the literature on children and young people also helps us to extend our spatial focus beyond Western capitalist economies and in some cases beyond spaces traditionally envisaged as sites of education. Ansell (2008), for example, takes the AIDS pandemic in Africa as her background as she examines the restructuring of the school system in Lesotho. Her particular focus is upon the changing role of the state in 
social reproduction in a context where significant numbers of young people can no longer rely on family, either because they have been orphaned or because they have become carers themselves. She uncovers evidence of an expansion of the role of schools into the sphere of social reproduction (such as teaching life skills and providing support that would previously have been done through the family), but finds that many initiatives are small scale, and concentrate on meeting students' social needs so that their educational needs can then be addressed (for example by providing food because this enables attendance and therefore learning). In a situation where there is little economic rationale for focusing on the reproduction of workers (as there are already large pools of underemployed people), providing for the needs of AIDS-affected children is based on an ethics of responsibility, and as a consequence if 'schools are to assist more adequately in securing the daily reproduction needs of Lesotho, education needs to be seen in terms other than producing a workforce of the future' (Ansell, 2008: 821).

A focus on the global South has also demanded that new questions are asked, and new spaces of education come into view. Research into economic activity amongst young people, for example, forces us to question the assumption that pre-school provision, schools, colleges and universities are the primary loci of education. Instead, it obliges us to consider other spaces including the home, spaces of subsistence agriculture, family businesses, and paid work in which children are learning the skills necessary for their current and future economic survival. Moreover, urgent attention is needed to consider the ways in which these diverse 'educational' and 'learning' spaces are being disrupted and changed in the context of the expansion of capitalist relations, urbanisation, environmental degradation and so on (Katz, 1991, 2004; Aitken et al., 2006).

In summary, the suggestion that we explore what the restructuring of education tells us about the contemporary state is a highly productive one, and one that can be further enhanced by drawing on the lessons from the literature on children, youth and families. Specifically, insights from this literature suggest expanding the spaces of education we might study and highlight the need to assess the implications of restructuring in these for diverse social groups. Furthermore it foregrounds the need to move beyond a focus on advanced capitalist economies to consider what the restructuring of 'educational' spaces in the global South might mean. 


\section{Conclusion}

Our purpose in this paper has been to explore how the inclusion of social-cultural research on children, youth and families might reshape our understandings of what has already been, and might be, achieved through geographies of education. First and foremost, what our analysis demonstrates is that the inclusion of this research changes the interpretation of past achievements and sets new agendas for research by moving the subjects of education -- the children, young people and adults involved in learning and teaching -- into the foreground. In the context of universities, for example, putting students first will allow us to move beyond economic studies of universities' capacity to stimulate regional economic growth and innovation, and to produce different insights into the imprint of universities in their localities and regions, as well as their wider transnational networks, for example through studies of studentification, student migration, and youth cultures. In the case of the school curriculum, putting pupils first widens our focus beyond the remaking of self-evidently geographical identities through formal curriculum provision, and instead highlights the importance of analysing young people's experiences in educational spaces and the (re)production of a wider diversity of social identities through the delivery and consumption of the formal and informal curricula, exploring the ways that adult ideas about childhood, youth and students shape the design and use of educational spaces.

At one level, this new agenda for geographies of education can be viewed as additive; drawing on the literature on children, youth and families extends the list of topics that geographies of education might study. Underlying this, however, is an important change in the way we think about those who are being educated. Rather than relying on adultist formulations which cast young people as the objects of education, geographies of education which draw on insights from social-cultural work on children, youth and families will need to focus on the voices and subjectivities of young people. This will allow us to highlight the importance of young people's experiences of education in the here and now, as well having concern for education's future impacts, encouraging us to engage with young people as knowledgeable actors whose current and future lifeworlds are worthy of investigation. Adopting this approach will require research that links an inward-looking focus on educational spaces with an outward-looking approach that assesses their importance to other time/spaces. Our agenda for geographies of education is then one which transcends the inward-outward dichotomy, and engages both with the ways education is bounded into/and shapes wider 
social/economic/political processes, and at the same time considers how this is experienced by the pupils/students, families and educators in the spaces of learning which form key sites of interaction in their everyday lives.

Secondly, this paper demonstrates that including research on children, youth and families forces us to extend the spatial lens of geographies of education in three ways. In conceptual terms, we need to expand our interpretation of what count as spaces of education. Traditional sites of education such as schools and universities remain important in our envisioning of the field of research, but we must also pay greater attention to the home, pre-school provision, neighbourhood spaces and after-school care, as well as thinking more deeply about the ways people learn in subsistence agriculture, family businesses, paid work and so on. In geographical terms, the inclusion of literature on children, youth and families has the effect of challenging the Northern centricity in geographies of education research agenda, and we have been able to point to some exceptional examples of research in the global South that lead the way, and which might usefully inform research in the global North. However, there is no doubt that there is still a relative paucity of research on geographies of education in the global South, a paucity which is particularly stark in some areas of research, and our future agenda must therefore adopt a more balanced global vision.

In methodological practice, these different ways of broadening our spatial lens also requires us to consider spatial networks. Rather than focusing on education within specific sites, we need to trace the webs of connections between, for example, home and school, showing how socio-spatial practices in each shape children, youth and families' experiences of both sites. Equally, in focusing on the global North and global South we must produce studies which link the two (as well as studies which provide in-depth accounts of each), for example through a focus on the global geographies of higher education. Indeed, there is also scope for combining all these aspects in global studies of diasporas, tracing the ways in which links between home, neighbourhood and school/university in places that stretch across the globe shape people's educational experiences and future life chances.

In setting forth our complementary reading of the achievements and future agenda in geographies of education, we are mindful of the difficulties of producing an inclusive review of a body of research that is neither clearly bounded, nor obviously defined by sub-disciplinary structures or language contexts. Our strategy has been deliberately to 
foreground research that draws on geographies of children, youth and families in order to produce a different overview of what has been and might be achieved, thus creating another point of reference for scholars pursuing the 'spatial turn' in education studies (Gulson and Symes, 2007). We have no doubt that our partiality will lead others to critique the worldview put forward in this paper. For us this is not a risk, but an opportunity to further stimulate debate in a vibrant area of research in which we are privileged to work.

${ }^{1}$ In the context of the International Geographical Union (IGU), a working party on ‘Geography of Education’ produced five bulletins between 1972 and 1981 (Hones and Ryba, 1972a). The working group ‘Geography of Education’ of the German Society for Geography (DGfG) was founded in 1983 and has recently completed a large-scale interdisciplinary project in the form of a volume 'Education and Culture' of the National Atlas of Germany (Institut für Länderkunde, 2002).

2 The particularly well-developed research tradition on geographies of education in German-speaking countries provides an important context for our discussion of children, youth and families in geographies of education, with Meusburger's (1998) comprehensive review of the field focusing on both variation in access and attainment in education. Indeed, over the past decade, German language research on the geographies of education has put an emphasis on the educational attainment of ethnic minorities in different cultural contexts, noting the complex negotiations that occur between the educational objectives of formal school curricula and informal family traditions (see Freytag, 2003a, 2003b; Meusburger, 2003; Pott, 2004; Gamerith, 2005).

\section{Acknowledgements}

Dr Sarah Holloway is a Philip Leverhulme Prize winner and gratefully acknowledges The Leverhulme Trust's support for her research.

\section{References}

Aitken, S., Estrada, S.L., Jennings, J. and Aguirre, L.M. 2006: Reproducing life and labour: global processes and working children in Tijuana, Mexico. Childhood 13, 36587. 
Allinson, J. 2006: Over-educated, over-exuberant and over here? The impact of students on cities. Planning Practice and Research 21, 79-94.

Altbach, P.G. 2003: The costs and benefits of world-class universities. International Higher Education 33, 5-8.

Ansell, N. 2001: 'Because it’s our culture!' (Re)negotiating the meaning of Lobola in southern African secondary schools. Journal of Southern African Studies 27, 697-716.

Ansell, N. 2002: ‘Of course we must be equal but...’: imagining gendered futures in two rural southern African secondary schools. Geoforum 33, 179-94.

Ansell, N. 2008: Substituting for families? Schools and social reproduction in AIDSaffected Lesotho. Antipode 40, 802-24.

Benneworth, P. S. and Charles, D. R. 2005: University spin-off companies and the territorial knowledge pool: building regional innovation competencies? European Planning Studies, 13, 537-57.

Blumen, O. 2002: Women's professional choice in geography: national sentiments and national exclusion. Women’s Studies International Forum 25, 555-71.

Bondi, L. and Domosh, M. 1992: Other figures in other places: on feminism, postmodernism and geography. Environment and Planning D: Society and Space 10, 199-213.

Bondi, L. and Matthews, M.H., editors, 1988: Education and society: studies in the politics, sociology and geography of education. London: Routledge.

Bradford, M. 1990: Education, attainment and the geography of school choice. Geography 75, 3-16.

Bradford, M.B., Bondi, L., Burdett, F, Peck, J., Quirk, B., editors, 1989: Education, space, and locality. London: Croom Helm.

Brooks, R. and Waters, J. 2009: International higher education and the mobility of UK students. Journal of Research in International Education 8, 191-209.

Burgess, S. and Wilson, D. 2005: Ethnic segregation in England's schools. Transactions of the Institute of British Geographers 30, 20-36. 
Burgess, S., Johnston, R., Key, T., Propper, C. and Wilson, D. 2008: The transition of pupils from primary to secondary school in England. Transactions of the Institute of British Geographers 33, 388-403.

Butler, J. 1993: Bodies that matter: on the discursive limits of `sex'. London: Routledge.

Butler, T. and Hamnett, C. 2007: The geography of education: introduction. Urban Studies 44, 1161-74.

Canaan, J.E. and Shumar, W., editors, 2008: Structure and agency in the neoliberal university. London: Routledge.

Cao, H.H. 2008: Spatial inequality in children's schooling in Gansu, Western China: reality and challenges. Canadian Geographer 52, 331-50.

Chatterton, P. 1999: University students and city centres: the formation of exclusive geographies. Geoforum 30, 117-33.

Cochrane, A. and Etherington, D. 2007: Managing local labour markets and making up new spaces of welfare. Environment and Planning A 39, 2958-74.

Collins, D. 2006: Culture, religion and curriculum: lessons from the 'three books' controversy in Surrey, B.C. Canadian Geographer 50, 342-57.

Collins, D. 2007: Legal geographies, legal sense and geographic context: court rulings on religious activities in public schools. Urban Geography 28, 181-97.

Collins, D. and Coleman, T. 2008: Social geographies of education: looking within, and beyond, school boundaries. Geography Compass 2, 281-99.

De Leeuw, S. 2007: Intimate colonialisms: the material and experienced places of British Columbia’s residential schools. Canadian Geographer 51, 339-59.

Esping-Andersen. 1990: The three worlds of welfare capitalism. Cambridge: Polity.

Evans, B. 2006: I'd feel ashamed': girls' bodies and sports participation. Gender, Place and Culture 13, 547-61.

Fincher, R. and Shaw, K. 2006: Transnational and temporary: place-making, students and community in central Melbourne. Planning News 32, 12-13. 
Findlay, A., King, R., Stam, A. and Ruiz-Gelices, E. 2006: Ever reluctant Europeans: the changing geographies of UK students studying and working abroad. European Urban and Regional Studies 13, 291-318.

Florida, R. 2002: The rise of the creative class. New York: Basic Books.

Freytag, T. 2003a: Bildungswesen, Bildungsverhalten und kulturelle Identität: Ursachen für das unterdurchschnittliche Ausbildungsniveau der hispanischen Bevölkerung in New Mexico. Heidelberg: Selbstverlag des Geographischen Instituts der Universität Heidelberg.

Freytag, T. 2003b: Mission schools, modernization, and mass education: Historical perspectives on a changing institutionalized education in New Mexico. In: Nemes Nagy, J., editor, Frontiers of geography: A selection from the wide range of geographical topics, Budapest: Eötvös Loránd Universität, 189-98.

Foote, K.E., Li, W., Monk, J. and Theobald, R. 2008: Foreign-born scholars in US universities: issues, concerns, and strategies. Journal of Geography in Higher Education 32, 167-78.

Gagen, E. 2004: Making America flesh: physicality and nationhood in early twentiethcentury physical education reform. Cultural Geographies 11, 417-42.

Gamerith, W. 2005: Das Bildungssystem der USA: Gute Schulen für alle? Geographische Rundschau 57, 38-45.

Geipel, R. 1968: Der Standort der Geographie des Bildungswesens innerhalb der Sozialgeographie. In: Hartke, W., Ruppert, K., editors, Zum Standort der Sozialgeographie, München: Lassleben, 155-61.

Geipel, R. 1976: Zur Entstehungsgeschichte des Forschungsansatzes ‘Geographie des Bildungsverhaltens‘. Mitteilungen der Österreichischen Geographischen Gesellschaft 118, 3-8.

Gibson, A. and Asthana, S. 2000: Local markets and the polarization of public-sector schools in England and Wales. Transactions of the Institute of British Geographers 25, 303-19.

Gould, W.T.S. 1993: People and education in the third world. New York: Longman. 
Gulson, K.N. and Symes, C. 2007: Spatial theories of education: policy and geography matters. London: Routledge.

Hall, S. 2008: Geographies of business education: MBA programmes, reflexive business schools and the cultural circuit of capital. Transactions of the Institute of British Geographers 33, 27-41.

Hanson Thiem, C. 2009: Thinking through education: the geographies of contemporary educational restructuring. Progress in Human Geography 33, 154-73.

Harloe, M. and Perry B. 2004:Universities, Localities and Regional Development: The Emergence of the 'Mode 2' University? International Journal of Urban and Regional Research 28, 212-23.

Harris, R., Johnston, R. and Burgess, S. 2007: Neighborhoods, ethnicity and school choice: developing a statistical framework for geodemographic analysis. Population Research and Policy Review 26, 553-79.

Hemming, P.J. 2007: Renegotiating the primary school: children's emotional geographies of sport, exercise and active play. Children's Geographies 5, 353-71.

Hemming, P.J. 2009: School spaces of belonging: education children for religious citizenship. Geographies of Education Conference, 8-9 $9^{\text {th }}$ September, Loughborough Unversity, UK.

Heffernan, M. and Jöns, H. 2007: Degrees of influence: The politics of honorary degrees in the universities of Oxford and Cambridge, 1900-2000. Minerva: A Review of Science, Learning and Policy 45, 389-416.

Holdsworth, C. 2006: 'Don't you think you're missing out, living at home?' Student experiences and residential transitions. Sociological Review 54, 495-519.

Holloway, S.L. 1998: Local childcare cultures: moral geographies of mothering and the social organisation of pre-school education. Gender, Place and Culture 5, 29-53.

Holloway, S.L. 1999: Mother and worker? The negotiation of motherhood and paid employment in two urban neighbourhoods. Urban Geography 20, 438-60. 
Holloway, S.L., Valentine, G. and Bingham, N. 2000: Institutionalising technologies: masculinities, femininities, and the heterosexual economy of the IT classroom. Environment and Planning A 32, 617-33.

Holloway, S.L. and Pimlott-Wilson, H. 2009: Dumped here or escaping there: class, childhood and community in head teacher interpretations of the Extended School initiative. Geographies of Education Conference, 8- $9^{\text {th }}$ September, Loughborough Unversity, UK.

Holt, L. 2007: Children's sociospatial (re)producation of disability within primary school playgrounds. Environment and Planning D: Society and Space 25, 783-802.

Hones, G. and Ryba, R. 1972a: Bulletin no. 1 of the working party on the geography of education. Manuscript.

Hones, G. and Ryba, R. 1972b: Why not a geography of education? The Journal of Geography 71, 135-39.

Hopkins, P. 2006: Youth transitions and going to university: the perceptions of students attending a geography summer school access programme. Area 38, 240-47.

Hoyler, M. and Jöns, H. 2008: Global knowledge nodes and networks. In Johnson, C., Hu, R. and Abedin, S., editors, Connecting Cities: Networks, Sydney: Metropolis, 12451.

Hubbard, P. 2008: Addressing the social costs of studentification. Environment and Planning A 40, 323-40.

Hyams, M. 2000: 'Pay attention in class...[and] don't get pregnant': a discourse of academic success among adolescent Latinas. Environment and Planning A 32, 635-54.

Institut für Länderkunde, editor, 2002: Nationalatlas Bundesrepublik Deutschland: Band 6: Bildung und Kultur. Heidelberg: Spektrum Akademischer Verlag.

Jeffrey, C., Jeffrey, P. and Jeffrey, R. 2004: 'A useless thing!’ or 'Nectar of the Gods?' The cultural production of education and young men's struggles for respect in liberalizing North India. Annals of the Association of American Geographers 94, 96181. 
Jeffrey, C., Jeffrey, P. and Jeffrey, R. 2007: Degrees without freedom? Education, masculinities, and unemployment in north India. Stanford, CA: Stanford University Press.

Jessop, B. 2002: The future of the capitalist state. Cambridge: Polity Press.

Johnston, R., Wilson, D. and Burgess, S. 2007: Ethnic segregation and educational performance at secondary school in Bradford and Leicester. Environment and Planning A 39, 609-29.

Jöns, H. 2009: ‘Brain circulation’ and transnational knowledge networks: Studying long-tem effects of academic mobility to Germany, 1954-2000. Global Networks 9, 315-38.

Katz, C. 1991: Sow what you know: the struggle for social reproduction in rural Sudan. Annals of the Association of American Geographers 81, 488-514.

Katz, C. 2004: Growing up global: economic restructuring and children’s everyday lives. Minneapolis: University of Minnesota Press.

Kearns, R., Collins, D.C.A and Neuwelt, P.M. 2003: The walking school bus: extending children's geographies? Area 35, 285-92.

King, R. and Ruiz-Gelices, E. 2003: International student migration and the European 'year abroad': effects on European identity and subsequent migration behavior. International Journal of Population Geography 9, 229-52.

Kong, L. 2005: Religious schools: for spirit, (f)or nation. Environment and Planning D: Society and Space 23, 615-31.

Kraftl, P. 2006a: Ecological architecture as performed art: Nant-y-Cwn Steiner School, Pembrokeshire. Social and Cultural Geography 7, 927-48.

Kraftl, P. 2006b: Building an idea: the material construction of an ideal childhood. Transactions of the Institute of British Geographers 31, 488-504.

Lambooy, J.G. 1997: Knowledge production, organisation and agglomeration economies. Geojournal 41, 293-300.

Lawton Smith, H. 2006: Universities, innovation and the economy. London: Routledge. 
Lees, L., Slater, T. and Wyly, E. 2007: Gentrification. London: Routledge.

Mahon, R. 2005: Rescaling social reproduction: childcare in Toronto/Canada and Stockholm/Sweden. International Journal of Urban and Regional Research 29, 341-57.

Marginson, S. and Considine, M. 2000: The enterprise university: power, governance, and reinvention in Australia. Cambridge: Cambridge University Press.

Marsden, W.E. 1977: Historical geography and history of education. History of Education 6, 21-42.

Marsden, W.E. 2001: The school textbook: geography, history, and social studies. London: Routledge.

McDowell, L., Ray, K., Perrons, D., Pagan, C. and Ward, K. 2005: Women's paid work and moral economies of care. Social and Cultural Geography 6, 219-35.

Meusburger, P. 1976: Entwicklung, Stellung und Aufgaben einer Geographie des Bildungswesens. Eine Zwischenbilanz. Mitteilungen der Österreichischen Geographischen Gesellschaft 118, 9-54.

Meusburger, P. 1998: Bildungsgeographie: Wissen und Ausbildung in der räumlichen Dimension. Heidelberg: Spektrum Akademischer Verlag.

Meusburger, P. 2003: Culture, pouvoir et scolarité dans Les États-nations multiethniques: Contextes culturels et géographie du savoir. Geographie et Cultures 47, 6784.

Nairn, K. 2003: What has the geography of sleeping arrangement got to do with the geography of our teaching spaces? Gender, Place and Culture 10, 67-81.

Olds, K. 2007: Global assemblage: Singapore, foreign universities, and the construction of a 'global education hub'. World Development 35, 959-75.

Patiniotis, J. and Holdsworth, C. 2005: 'Seize that chance!': leaving home and transitions to higher education. Journal of Youth Studies 8, 81-95.

Peck, J. and Theodore, N. 2001: Exporting workfare/importing welfare-to-work: exploring the politics of Third Way policy transfer. Political Geography 20, 427-460. 
Philo, C. and Parr, H., 2000: Institutional geographies: introductory remarks. Geoforum $31,513-21$.

Pike, J. 2008: Foucault, space and primary school dining rooms. Children's Geographies 6, 413-22.

Pooley, C.G., Turnbull, J. and Adams, M. 2005: The journey to school in Britain since the 1940s: continuity and change. Area 37, 43-53.

Pott, A. 2004: Ethnizität und Lokalität als Aufstiegsressourcen: Theoretische Überlegungen und das Beispiel des Bildungsaufstiegs in der zweiten türkischen Migrantengeneration in Deutschland. Erdkunde 58, 42-52.

Punch, S. 2002: Youth transitions in interdependent adult-child relations in rural Bolivia. Journal of Rural Studies 18, 123-33.

Punch, S. 2004: The impact of primary education on school-to-work transitions for young people in rural Bolivia. Youth and Society 36, 163-82.

Reay, D. 2007: 'Unruly places': inner-city comprehensives, middle-class imaginaries and working-class children. Urban Studies 44, 1191-201.

Ross, N.J. 2007: ‘My journey to school...’' foregrounding the meaning of school journeys and children's engagements and interactions in their everyday localities. Children's Geographies 5, 373-91.

Roy, S. 2009: 'Expressing identities and experiencing difference: Spatial practices in the everyday lives of Indian students in London’ paper to Geographies of Education conference, Loughborough University $8-9^{\text {th }}$ Sept.

Rugg, J., Ford, J. and Burrows, R. 2004: Housing advantage? The role of student renting in the constitution of housing biographies in the United Kingdom. Journal of Youth Studies 7, 123-38.

Rutten, R., Boekema, F. and Kuijpers, E. 2003: Economic Geography of Higher Education: Knowledge Infrastructure and Learning Regions. London: Routledge.

Sadlak, S. and Liu, N.C., editors, 2007: The world-class university and ranking: aiming beyond status. Bucharest: UNESCO-CEPES. 
Schwanen, T. 2007: Gender differences in chauffeuring children among dual-earner families. Professional Geographer 59, 447-62.

Smith, D. 2005: Studentification: The gentrification factory? In Atkinson, R. and Bridge, G., editors, The new urban colonialism: gentrification in a global context, London: Routledge, 72-89.

Smith, D. 2008: The politics of studentification and 'unbalanced' urban populations: lessons for gentrification and sustainable communities. Urban Studies 45, 2547-64.

Smith, D. and Holt, L. 2007: Studentification and 'apprentice' gentrifiers within Britain’s provincial urban locations: extending the meaning of gentrification? Environment and Planning A 39, 142-61.

Smith, F. and Barker, J. 2000: Out of school, in school: a social geography of out of school care. In Holloway, S.L. and Valentine, G., editors, Children’s geographies: playing, living, learning, London: Routledge, 245-56.

Smith, F. and Barker, J. 2001: Commodifying the countryside: the impact of out-ofschool care on rural landscapes of children's play. Area 33, 169-76.

Smith, F. and Barker, J. 2004: Inclusive environments? The expansion of out-of-school child care in the UK. Children, Youth and Environments14, 1-20.

Smith, F., Barker, J., Wainwright, E., Marandet, E. and Buckingham, S. 2008: A new deal for lone parents? Training lone parents for work in West London. Area 40, 237-44.

Taylor, C. and Gorard, S. 2001: The role of residence in school segregation: placing the impact of parental choice in perspective. Environment and Planning A 33, 1829-52.

Theobald, R.B. 2008: Internationalization: institutions, people and programmes in Colorado. Journal of Geography in Higher Education 32, 205-16.

Thomas, M.E. 2005: 'I think it's just natural': the spatiality of racial segregation at a US high school. Environment and Planning A 37, 1233-48.

Thomas, M.E. 2008: The paradoxes of personhood: banal multiculturalism and racialethnic identification among Latina and Armenian girls at a Los Angeles high school. Environment and Planning A 40, 2864-78 
Thomson, S. 2005: 'Territorialising' the primary school playground: deconstructing the geography of playtime. Children's Geographies 3, 63-78.

Valentine, G., Holloway, S.L. and Bingham, N. 2002: The digital generation?: Children, ICT and the everyday nature of social exclusion. Antipode 34, 296-315.

Valins, O. 2003: Defending identities or segregating communities? Faith-based schooling and the UK Jewish community. Geoforum 34, 235-47.

Vanderbeck, R.M. 2005: Anti-nomadism, institutions, and the geographies of childhood. Environment and Planning D: Society and Space 23, 71-94.

Vorley, T. and Lawton Smith, H. 2007: Universities and the knowledge based economy. Environment and Planning C 25: 775-78.

Warrington, M. 2005: Mirage in the desert? Access to educational opportunities in an area of social exclusion. Antipode 37, 796-816.

Waters, J.L. 2005: Transnational family strategies and education in the contemporary Chinese diaspora. Global Networks 5, 359-78.

Webber, R. and Butler, T. (2007) Classifying pupils by where they live: how well does this predict variations in their GCSE results? Urban Studies 44, 1229-53. 